\title{
Analysis of OXA-204 carbapenemase-producing Enterobacteriaceae reveals possible endoscopy- associated transmission, France, 2012 to 2014
}

Anaïs Potron ${ }^{1,2}$, Sandrine Bernabeu ${ }^{1,3,4,5}$, Gaëlle Cuzon ${ }^{1,3,4,5}$, Valérie Pontiès ${ }^{6}$, Hervé Blanchard ${ }^{7}$, Elise Seringe ${ }^{7}$, Thierry Naas ${ }^{1,3,4,5}$,

Patrice Nordmann ${ }^{8,9,10,11}$, Laurent Dortet ${ }^{1,3,4,5}$

1. National Reference Centre for Antibiotic Resistance, (division of carbapenemase-producing Enterobacteriaceae), Le KremlinBicêtre, France

2. Department of Bacteriology, University Hospital of Besançon, Université of Franche-Comté, Besançon, France

3. Bacteriology-Hygiene Unit, Assistance Publique/Hôpitaux de Paris, Bicêtre Hospital, Le Kremlin-Bícêtre, France

4. EA7361 "Structure, Dynamic, Function and Expression of Broad Spectrum beta-Lactamases", Paris-Sud University, LabEx Lermit, Faculty of Medicine, Le Kremlin-Bicêtre, France

5. Joint Research Unit EERA “Evolution and Ecology of Resistance to Antibiotics," Institut Pasteur-APHP-Université Paris-Sud, Paris, France

6. Santé Publique France, The French Public Health Agency, Saint-Maurice, France

7. Regional Coordinating Centre for Nosocomial Infection Control (C-CLIN Paris Nord), Paris, France.

8. Emerging Antibiotic Resistance Unit, Medical and Molecular Microbiology, Department of Medicine, University of Fribourg, Fribourg, Switzerland

9. Institut National de la Santé et de la Recherche Médicale (INSERM) European Unit (LEA Paris, IAME, France), University of Fribourg, Switzerland

10. National Reference Centre for Emerging Antibiotic Resistance, Fribourg, Switzerland

11. Institute for Microbiology, University hospital and University of Lausanne, Lausanne, Switzerland

Correspondence: Laurent Dorte (laurent.dortet@aphp.fr)

Citation style for this article:

Potron Anaïs, Bernabeu Sandrine, Cuzon Gaëlle, Pontiès Valérie, Blanchard Hervé, Seringe Elise, Naas Thierry, Nordmann Patrice, Dortet Laurent. Analysis of OXA204 carbapenemase-producing Enterobacteriaceae reveals possible endoscopy-associated transmission, France, 2012 to 2014. Euro Surveill. 2017;22(49):pii=1700048. https://doi.org/10.2807/1560-7917.ES.2017.22.49.17-00048

OXA-48-like beta-lactamase producing bacteria are now endemic in several European and Mediterranean countries. Among this carbapenemase family, the OXA48 and OXA-181 variants predominate, whereas other variants such as OXA-204 are rarely reported. Here, we report the molecular epidemiology of a collection of OXA-204-positive enterobacterial isolates $(n=29)$ recovered in France between October 2012 and May 2014. This study describes the first outbreak of OXA204-producing Enterobacteriaceae in Europe, involving 12 isolates of an ST9o Escherichia coliclone and nine isolates of an ST147 Klebsiella pneumoniae clone. All isolates co-produced the cephalosporinase CMY-4, and $60 \%$ of them co-produced the extended-spectrum beta-lactamase CTX-M-15. The bla $a_{\text {OXA-204 }}$ gene was located on a $150-\mathrm{kb}$ IncA/C plasmid, isolated from various enterobacterial species in the same patient, indicating a high conjugative ability of this genetic vehicle.

\section{Introduction}

Since the 2000s, the carbapenem-hydrolysing betalactamase OXA-48 has rapidly and widely disseminated and is now endemic in several European and Mediterranean countries [1-4]. Since its discovery, eleven variants of OXA-48 have been reported, classified into two main groups $[1,5-13]$. The first group contains variants with significant carbapenemase activity, such as OXA-48, OXA-162, OXA-181 or OXA-204 [5-7]. Some variants, such as OXA-232 and OXA-244, possess a hydrolytic profile similar to that of OXA-48 but have a lower capacity to hydrolyse imipenem and temocillin [8-10]. The second group of OXA-48-like variants includes beta-lactamases with extended-spectrum hydrolysis properties and without any significant carbapenemase activity because of deletions in the active site of the enzyme, such as OXA-163, OXA-247, or OXA-405 [11-13]. In most of these cases, the bla ${ }_{\text {OXA- } 48}$ like genes are plasmid-borne and are associated with insertion sequences involved in their mobilisation and expression $[1,7,9]$.

OXA-204 was first identified in 2012 in a Klebsiella pneumoniae isolate from Tunisia [7]. In this strain, the bla $a_{\text {OXA-204 }}$ was CO-located with a bla $a_{\text {СMY-4 }}$ gene on a conjugative IncA/C-type plasmid [7]. The bla ${ }_{\text {OxA-204 }}$ gene was part of a transposon Tn2016 that consisted of one copy of insertion sequence (IS) ISEcp1, disrupted by an ISKpn15 element, and a truncated lysR transcriptional regulator [7]. Since that report, OXA-204 has only been identified in two other $K$. pneumoniae isolates and a single Escherichia coli isolate, all recovered in Tunisia $[14,15]$. In those two strains, the bla $a_{\text {OXA-204 }}$ gene was 


\section{FIGURE 1}

Rep-PCR analysis of OXA-204-producing

Enterobacteriaceae, France, 2012-14 ( $=21)$

A.

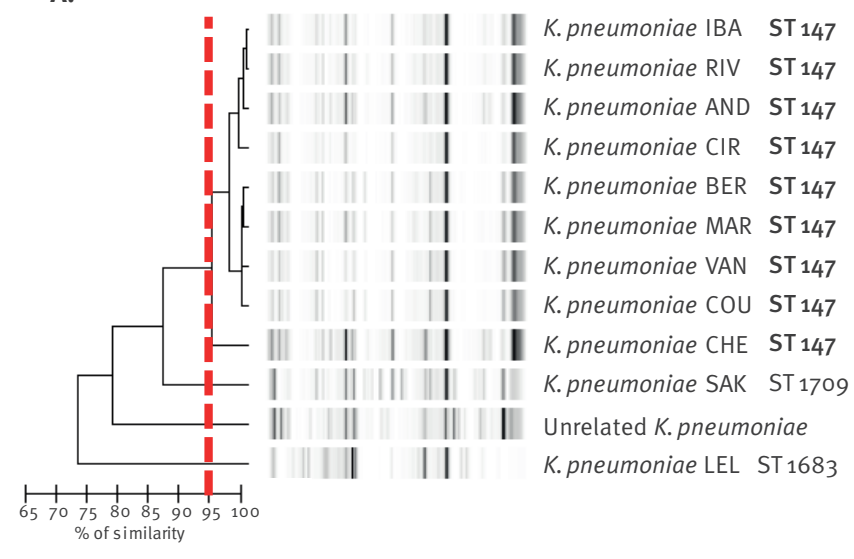

B.

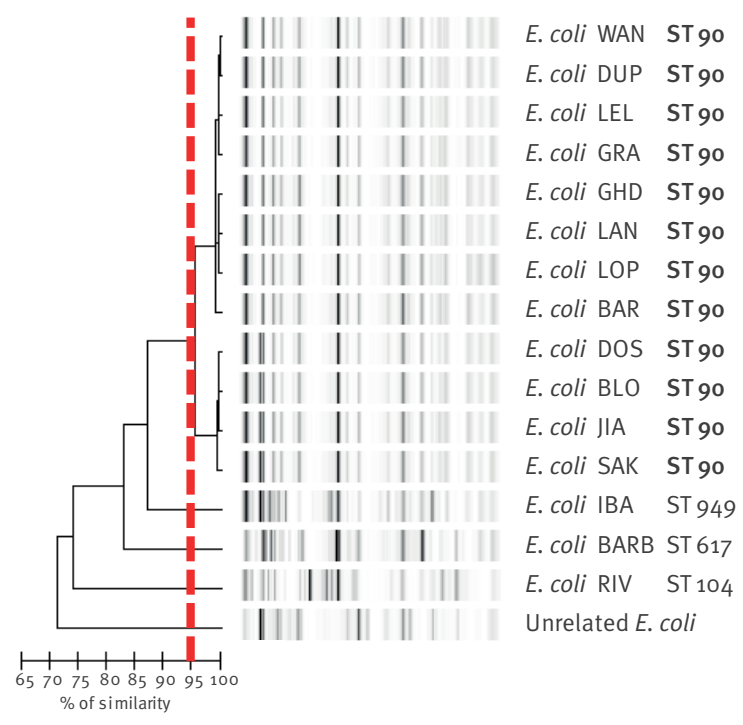

Dendrogram and computer-generated image of rep-PCR banding patterns of OXA-204-producing Klebsiella pneumoniae (A) and OXA-204-producing E. coli (B) isolates. Epidemic clones (ST90 Escherichia coli and ST147 K. pneumoniae are highlighted in bold. The red similarity line at $95 \%$ shows the cut-off to separate different clone.

associated with the ISECP1 element, in one of the two cases truncated by another IS element $[14,15]$.

Our study aimed to compare the genetic features of OXA-204 beta-lactamase-producing strains recovered in France by analysing a collection of 29 bla $a_{0 \times A-204}$-positive enterobacterial isolates recovered from October 2012 to May 2014. The genetic context and the location of the bla ${ }_{\text {OXA-204 }}$ gene were investigated. Finally, a clonal relationship analysis allowed us to identify a regional outbreak in France possibly related to an endoscope.

\section{Methods}

\section{Bacterial isolates}

We investigated a total of 29 OXA-204 beta-lactamase-producing enterobacterial isolates. All isolates had been recovered from clinical specimens and had been received between October 2012 and May 2014 at the National Reference Centre (NRC) for Antibiotic Resistance (division of carbapenemase-producing Enterobacteriaceae), France. The distribution of clinical samples was as follows: 12 rectal swabs, 12 urine samples, four bile samples and one pus specimen. Isolates were identified using matrix-assisted laser desorption ionization time-of-flight (MALDI-TOF) mass-spectrometry (Maldi Biotyper, Bruker Daltonics, France).

\section{Susceptibility testing}

Antimicrobial susceptibilities were determined by disk diffusion method on Mueller-Hinton agar (Bio-Rad, Marnes-la-Coquette, France) and interpreted according to the European Committee on Antimicrobial Susceptibility Testing (EUCAST) guidelines [16]. In addition, minimal inhibitory concentrations (MICs) were determined for carbapenems (imipenem, meropenem, ertapenem) and tigecycline using E-tests (bioMérieux, Marcy-l'Etoile, France), and for colistin using broth microdilution according to EUCAST recommendations.

\section{PCR and sequencing of beta-lactamase- encoding genes}

Whole-cell DNA was extracted using the QiaAmp DNA minikit (Qiagen, Courtaboeuf, France). All isolates were screened by PCR for the Ambler class A, B and D carbapenemase-encoding genes bla $a_{\mathrm{KPC}}$, bla $a_{\mathrm{IMP}}, b l a_{\mathrm{VIM}}$, bla $a_{\mathrm{NDM}}$ and bla $a_{\mathrm{OXA}-48 \text {-like }}$ as previously described $[6,17,18]$. Detection of other beta-lactamase genes such as bla ${ }_{\text {CTX-M }}$ and bla ${ }_{\text {AmpC. }}$ like was performed with internal primers, as described previously [17]. PCR products were analysed on agarose gel. In case of positive signal, the full-length genes (basically bla $a_{\text {СTX-M }}$ and $b / a_{\text {СMY }}$ ) were amplified and sequenced by using the amplification primers with an automated sequencer (ABI PRISM 3100; Applied Biosystems) as previously described [17]. The nucleotide and deduced protein sequences were analysed with software from the National Center for Biotechnology Information (www.ncbi.nlm.nih.gov).

\section{Strain typing}

Multilocus sequence typing (MLST) with seven housekeeping genes (rpoB, gapA, $m d h, p g i, p h o E$, infB and $t$ on $B$ ) was performed for K. pneumoniae isolates according to Diancourt et al. [19]. Allele sequences and sequence types (STs) were verified at the Institut Pasteur's whole genome MLST database [20]. Fragments of seven housekeeping genes ( $a d k$, fum $C$, gyrB, icd, $m d h$ , purA and recA) were amplified and sequenced for $E$. coli isolates as described on EnteroBase [21]. A different allele number was given to each distinct sequence within a locus, and a distinct ST number was attributed to each distinct combination of alleles. 
Synoptic curve of patients involved in the endoscope-related outbreak caused by OXA-204-producing Enterobacteriaceae, France, 2012-14 $(\mathrm{n}=22)$

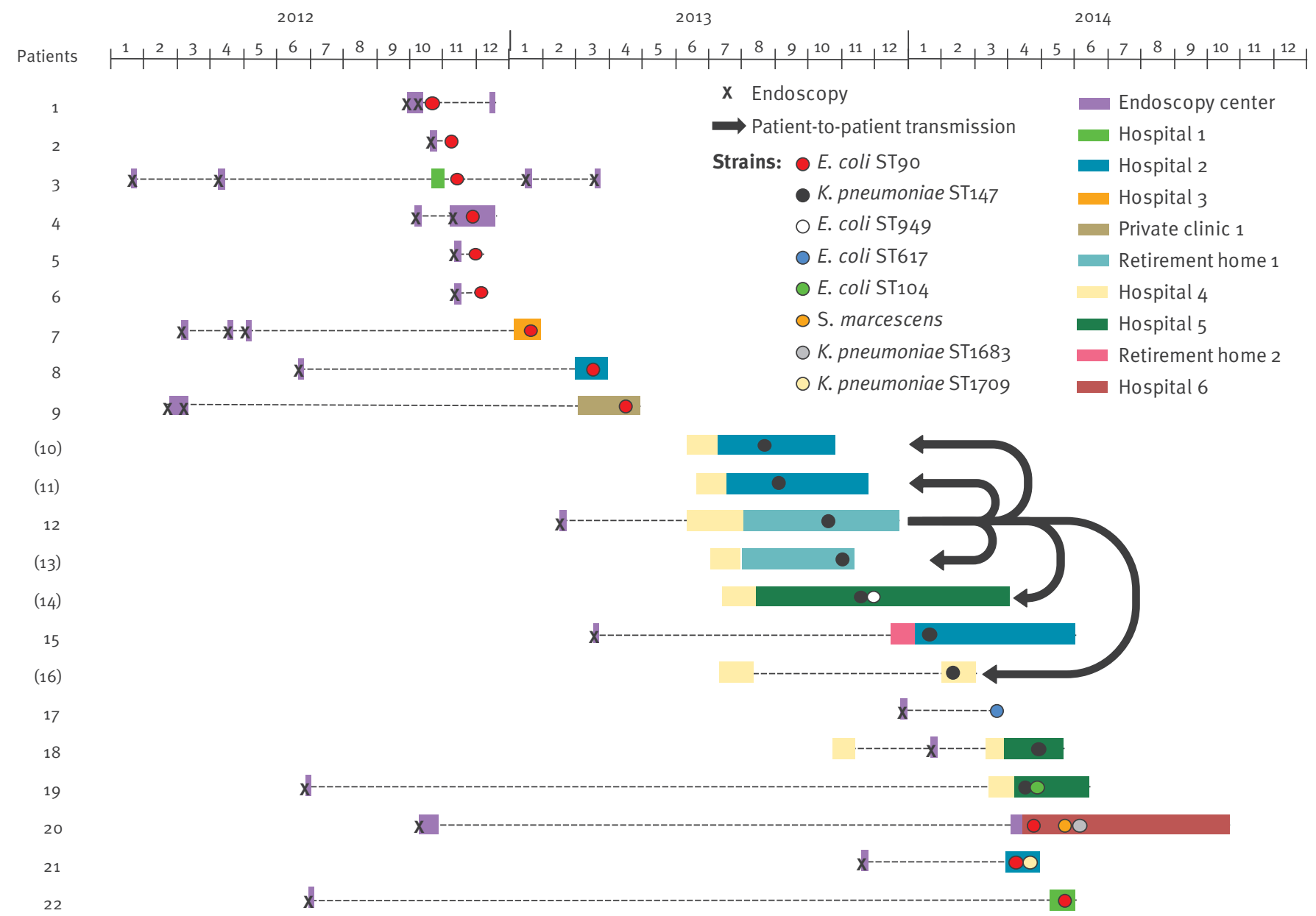

Patient numbers are indicated on the left of each time line. Numbers in parenthesis indicate patients who were not in direct contact with the suspectedly contaminated endoscope. Crosses indicate the date of endoscopy with the suspectedly contaminated endoscope and coloured boxes correspond to hospitalisations. Black arrows represent direct patient-to-patient transmission of the 0XA-204-producing K. pneumoniae ST147.

Clonality analysis using repetitive element palindromic PCR (rep-PCR)

To evaluate their clonal relationship, all $E$. coli and $K$. pneumoniae isolates were subjected to Diversilab, a semi-automated rep-PCR (bioMérieux, Marcy-L'Etoile, France). As recommended by the manufacturer, a cutoff for similarity of $95 \%$ defined a cluster.

\section{Plasmid DNA analysis and mating-out assays} Plasmid DNAs were extracted using the Kieser method [22], and analysed by agarose gel electrophoresis using the $E$. coli NCTC50192 strain that harbours four plasmids of $154,66,48$ and $7 \mathrm{~kb}$ as plasmid size marker. Direct transfer of the carbapenem resistance markers was attempted by liquid mating-out assays at $37^{\circ} \mathrm{C}$ using sodium azide-resistant E. coli J53 as recipient, as previously described [23]. Selection was performed on agar plates supplemented with ertapenem $(0.5 \mu \mathrm{g} / \mathrm{mL})$ and sodium azide $(100 \mu \mathrm{g} / \mathrm{mL})$.

\section{Replicon and transposon typing}

PCR-based replicon typing of the main plasmid incompatibility groups reported in Enterobacteriaceae was performed as previously described [24]. Genetic structures surrounding the $b a_{\mathrm{OXA}-204}$ gene were determined using the primers listed in Table 1.

\section{Results}

\section{Bacterial isolates}

A total of 29 OXA-204-producing enterobacterial isolates were received at the NRC for Antibiotic Resistance from October 2012 to May 2014. These isolates were sent to the NRC because they exhibited decreased susceptibility to carbapenems and/or because they were isolated from a patient who was identified in epidemiological investigations around an infected or colonised patient. These isolates included $11 \mathrm{~K}$. pneumoniae, 15 E. coli, one Proteus mirabilis, one Citrobacter freundii and one Serratia marcescens (Table 2). The 29 strains were isolated from 24 patients. Of these 29 
TABLE 1

Primers used for Tn2016 PCR mapping

\begin{tabular}{|l|c|c|}
\hline Primer & \multicolumn{1}{|c|}{ Sequence (5' to 3') } & $\begin{array}{c}\text { PCR product size } \\
\text { (bp) }\end{array}$ \\
\cline { 1 - 2 } ISEcp1A & TGCAGGTCTTTTTCTGCTCC & \multirow{2}{*}{1,099} \\
\hline ISKpn15-5'ext & CTGCGTGGCTATGTGCTCTG & \\
\hline ISKpn15-for & GGTGTTCGGTGACGAGATTAGC & \multirow{2}{*}{1,955} \\
\cline { 1 - 2 } OXA-48-5'ext & ATTCCAGAGCACAACTACGC & \multirow{2}{*}{998} \\
\hline ISEcp1P+ & TGCTCTGTGGATAACTTGCA & \\
\hline OXA48B & GAGCACTTCTTTTGTGATGGC & \\
\hline
\end{tabular}

OXA-204 producers, 27 were isolated from 22 patients $(n=22)$ located in the same geographical area (Paris area, lle-de-France).

Susceptibility to beta-lactams and related betalactamase genes

According to the EUCAST guidelines, 21 isolates were susceptible to imipenem and meropenem. Of the $15 E$. coliisolates, 14 were susceptible to imipenem and meropenem whereas only four of the $11 \mathrm{~K}$. pneumoniae isolates were susceptible to those antibiotics (Table 2). By contrast, 21 of the 29 OXA-204 producers had a decreased susceptibility (intermediate or resistant) to ertapenem (7/15 of the E. coli and 11/11 of the $K$. pneumoniae isolates). All P. mirabilis, $C$. freundii and S. marcescens isolates were susceptible to imipenem and meropenem and had decreased susceptibility to ertapenem (Table 2). Regarding the broadspectrum cephalosporins, all isolates were resistant to ceftazidime and cefotaxime. Since OXA-204 has no hydrolytic activity towards broad-spectrum cephalosporins, we searched for the expression of additional beta-lactamases (extended-spectrum beta-lactamases (ESBLs) and/or cephalosporinases). As expected, all OXA-204-producing isolates co-produced an AmpCtype beta-lactamase, CMY-4 (Table 2). In addition, 18 isolates were of intermediate susceptibility or resistant to cefepime (nine E. coli isolates and nine K. pneumoniae isolates). CMY-4 and OXA-204 are not able to hydrolyse cefepime, but co-production of the CTX-M-15 ESBL was found in all those isolates (Table 2).

\section{Susceptibility to non-beta-lactams antibiotics} Four antibiotics were active against the majority of the isolates. Except for the P. mirabilis and S. marcescens isolates that are intrinsically resistant to polymyxins, all other OXA-204 producers were susceptible to colistin. In addition, 28, 26 and 22 of the 29 OXA-204 producers were susceptible to amikacin, tigecycline and fosfomycin, respectively (Table 2). Conversely, 22 OXA-204 producers were resistant to sulfamethoxazole-trimethoprim, and 24 were resistant to ciprofloxacin and gentamicin (Table 2).

\section{Multilocus sequence typing}

STgo was the most commonly observed ST for the $E$. coli isolates, accounting for 12 of 15 isolates. The three remaining single isolates belonged to ST104, ST617 and ST949 (Table 2). Among the 11 OXA-204-positive $K$. pneumoniae isolates, nine isolates belonged to ST147. The remaining two isolates belonged to the new $\mathrm{ST}_{1} 683$ and ST1709 (Table 2).

\section{Genetic support of the $b l a_{\text {OXA-204 }}$ gene}

Using mating-out assays, transconjugants harbouring the $b l a_{\mathrm{OXA}-204}$ and the bla ${ }_{\mathrm{CMY}-4}$ genes were obtained for all 29 strains. Plasmid DNA analysis of those transconjugants revealed a single plasmid (ca $150 \mathrm{~kb}$ ), which was identified as an IncA/C-type plasmid (Table 2).

\section{Close genetic environment of the blaOXA-204 gene}

The genetic environment of the bla $a_{\mathrm{OXA}-204}$ gene was analysed using specific primers designed from the plasmid p204-B of K. pneumoniae 204 (Table 1). For 17 strains, the $b a_{\text {OXA-204 }}$ gene was part of transposon Tn2016, where ISECP1was disrupted by insertion of ISKpn15. This transposon was identified in the 12 STgo E. coli strains and in five other single isolates (Table 2). In the 12 remaining isolates (nine ST147 K. pneumoniae isolates and three single isolates), ISEcp1 was not disrupted by ISKpn15 element (Table 2).

\section{Endoscopy-related outbreak}

Rep-PCR analysis confirmed the MLST results and showed that 12 of the 15 OXA-204-producing $E$. coli isolates (all STgo E. coli) and nine of the 12 OXA204-producing K. pneumoniae isolates (all ST147 K. pneumoniae) were clonally related (Figure 1).

The results of this analysis led us to do an epidemiologically investigation of this dual outbreak (STgo E. coli and ST147 K. pneumoniae). An endoscope was identified as the possible source of the outbreak in that the investigation showed that 17 patients had direct contact with the endoscope, while five (Patients 10, $11,13,14$ and 16) were considered as secondary cases through patient-to-patient transmission on a clinical ward (Figure 2).

Of note, retrospective screening of all patients who had endoscopy with the suspectedly contaminated endoscope but were not hospitalised identified two colonised patients who underwent endoscopy as outpatients (Patients 6 and 17) (Figure 2). In addition, for four patients, transmission of a bla $a_{\mathrm{OXA}-204}$-carrying plasmid from one strain to another was observed (several enterobacterial isolates of different species carrying the same plasmid with the same close genetic environment for bla $_{\mathrm{OXA}-204}$ were isolated from patients 14, 19, 20 and 21; Figure 2 and Table 2). Finally, 14 patients were infected (four biliary infections, one hepatic abscess and nine urinary tract infections) and 12 patients were colonised. For one patient (Patient 19), the acquired biliary tract infection resulted in fatal 
Phenotypic and genetic features associated with OXA-204-beta-lactamase producing Enterobacteriaceae, France, 2012-14 $(\mathrm{n}=29)$

\begin{tabular}{|c|c|c|c|c|c|c|c|c|c|c|}
\hline \multirow{2}{*}{$\begin{array}{l}\text { Species / } \\
\text { clone }\end{array}$} & \multirow{2}{*}{$\begin{array}{l}\text { Number of } \\
\text { isolates }\end{array}$} & \multirow{2}{*}{$\begin{array}{l}\text { Sequence } \\
\text { type }\end{array}$} & \multicolumn{3}{|c|}{$\begin{array}{c}\text { Beta-lactams } \\
\text { MIC range }(\mu \mathrm{g} / \mathrm{mL})\end{array}$} & \multirow{2}{*}{$\begin{array}{c}\text { Genetic } \\
\text { location } \\
\text { of bla } a_{\mathrm{OXA}-204}\end{array}$} & \multirow{2}{*}{$\begin{array}{l}\text { Incompatibility } \\
\text { group of } \\
\text { bla } a_{\mathrm{oxA}-204}^{- \text {-carrying }} \\
\text { plasmid }\end{array}$} & \multirow{2}{*}{$\begin{array}{l}\text { Non-beta- } \\
\text { lactam- } \\
\text { associated } \\
\text { resistance } \\
\text { (number of } \\
\text { strains) }\end{array}$} & \multirow{2}{*}{$\begin{array}{l}\text { Associated broad- } \\
\text { spectrum beta- } \\
\text { lactamasesa(number } \\
\text { of strains) }\end{array}$} & \multirow{2}{*}{$\begin{array}{l}\text { Close genetic } \\
\text { environment } \\
\text { of the bla } a_{\text {oxA-2o: }} \\
\text { gene }\end{array}$} \\
\hline & & & ERT & IMP & MER & & & & & \\
\hline \multicolumn{11}{|c|}{ Escherichia coli } \\
\hline A & 12 & ST9o & $0.38-32$ & $0.19-12$ & $0.094-6$ & Plasmid & $\operatorname{Inc} A / C$ & $\begin{array}{l}\text { Gm (12), Tm } \\
\text { (12), Q (12), } \\
\text { Tet(12), Sxt } \\
\text { (10) }\end{array}$ & $\begin{array}{c}\text { CMY-4 (12), CTX-M- } \\
15 \text { (9) }\end{array}$ & Tn2016 \\
\hline$B$ & 1 & $\mathrm{ST} 104$ & 0.5 & 0.38 & 0.25 & Plasmid & $\operatorname{IncA} / \mathrm{C}$ & Tet & CMY-4 & ISEcp1 \\
\hline C & 1 & ST617 & 1 & 0.25 & 0.25 & Plasmid & $\operatorname{IncA} / \mathrm{C}$ & $\begin{array}{l}\text { Gm, Tm, Q, } \\
\text { Tet, Sxt }\end{array}$ & CMY-4 & Tn2016 \\
\hline D & 1 & ST949 & 0.75 & 0.5 & 0.19 & Plasmid & $\operatorname{lncA} / \mathrm{C}$ & Q, Tet, Sxt & CMY-4 & ISEcp1 \\
\hline \multicolumn{11}{|c|}{ Klebsiella pneumoniae } \\
\hline A & 9 & $\mathrm{ST} 147$ & $3-132$ & $1-12$ & $1-132$ & Plasmid & $\operatorname{Inc} A / C$ & $\begin{array}{c}\text { Ak (1), Tm (8), } \\
\text { Gm (6), Q (9), } \\
\text { Tet (9), Sxt } \\
\text { (8), Fos (7) }\end{array}$ & $\begin{array}{c}\text { CMY-4 (9), CTX-M-15 } \\
\text { (9) }\end{array}$ & ISEcp1 \\
\hline B & 1 & $\mathrm{ST} 1683 \mathrm{~b}$ & 3 & 0.25 & 0.19 & Plasmid & $\operatorname{Inc} A / C$ & Gm, Tm, Tet & CMY-4 & Tn2016 \\
\hline C & 1 & ST1709b & 1 & 0.25 & 0.12 & Plasmid & $\operatorname{IncA} / \mathrm{C}$ & $\begin{array}{l}\text { Gm, Tm, Tet, } \\
\text { Tig }\end{array}$ & CMY-4 & Tn2016 \\
\hline $\begin{array}{l}\text { Proteus } \\
\text { mirabilis }\end{array}$ & 1 & ND & 1.5 & 0.38 & 0.094 & Plasmid & IncA/C & Gm, Tm, Sxt & CMY-4 & ISEcp1 \\
\hline $\begin{array}{l}\text { Citrobacter } \\
\text { freundii }\end{array}$ & 1 & ND & 3 & 1 & 0.5 & Plasmid & $\operatorname{lnc} A / C$ & $\begin{array}{l}\text { Gm, Tm, Q, } \\
\text { Tet, Tig }\end{array}$ & CMY-4 & Tn2016 \\
\hline $\begin{array}{l}\text { Serratia } \\
\text { marcescens }\end{array}$ & 1 & ND & 0.75 & 0.75 & 0.5 & Plasmid & $\operatorname{Inc} A / C$ & $\begin{array}{l}\text { Gm, Tm, Tet, } \\
\text { Tig }\end{array}$ & CMY-4 & Tn2016 \\
\hline
\end{tabular}

Ak: amikacin; ERT: ertapenem; Fos: fosfomycin; Gm: gentamicin; IMP: imipenem; MER: meropenem; MIC: minimum inhibitory concentration; ND: not determinable; Q: quinolones; Sxt: sulfamethoxazole-trimethoprim; Tet: tetracycline; Tig: tigecycline; Tm: tobramycin.

a Resistance markers co-harboured on the bla $a_{0 \times A-204}$-carrying plasmid are underlined.

b ST1683 ad ST1709 are new sequence types.

septicaemia. Overall, this outbreak spread in 10 health institutions including one endoscopy centre where patients received the endoscopy with the suspected endoscope, six hospitals, one private clinic and two retirement homes (Figure 2).

In February 2014, the sequestration of the endoscope immediately stopped further detection of colonised patients, confirming that the endoscope was probably the source of this outbreak. However, audit of the reprocessing procedures that were performed in accordance with the manufacturer guidelines and French recommendations $[25,26]$ did not reveal any dysfunction. In microbiological investigations of the incriminated endoscope in February 2014, no OXA-204-producing strain was recovered from the device. However, polymorphic human flora was cultured from the endoscope and three additional reprocessing procedures were needed until the device was clean enough to conform with the French recommendations [26].

\section{Discussion}

We analysed different features of the OXA-204positive enterobacterial isolates collected between October 2012 and May 2014 at the NRC for Antibiotic Resistance (division of carbapenemase-producing Enterobacteriaceae), France.

According to the EUCAST guidelines, 21 of the 29 OXA204 producers remained susceptible to imipenem and meropenem, complicating their detection. Similar phenotypical characteristics have already been reported for OXA-48-producers [27]. OXA-204-producing $E$. coli seem to be more susceptible to those two carbapenems than OXA-204-producing $K$. pneumoniae. By contrast, ertapenem appeared to be the best carbapenem to detect those strains since 21 of the 29 isolates were resistant. All strains were resistant to extendedspectrum cephalosporins because of the production of the beta-lactamase CMY-4, thus limiting therapeutic options. In addition, 18 of the 29 OXA-204 producing isolates also produced a CTX-M-15-type ESBL, compromising the efficiency of cefepime. However, most of the 
isolates (27/29) remained susceptible to colistin, tigecycline, amikacin and fosfomycin.

We investigated the clonal distribution of OXA204-positive isolates and identified two main STs. Twelve of the $15 \mathrm{E}$. coli isolates belonged to STgo. To our knowledge, this ST has not been reported to be associated with OXA-48-like-producing E. coli. However, the occurrence of other carbapenemases such as NDM-1 had been reported twice in STgo E. coli isolates, and a link with India was demonstrated $[28,29]$. Nine of 11 the $K$. pneumoniae isolates belonged to ST147, which was the predominant ST in our study. The ST147 K. pneumoniae clone is linked to the worldwide spread of different carbapenemases (OXA48, OXA-204, NDM-1, NDM-5, VIM-1, KPC-2) and ESBL (SHV-12, CTX-M-15) $[15,27,30-33]$. Additional single STs were identified, namely ST617, ST104 and ST949 for $E$. coli and two new STs (ST1683 and ST1709) for K. pneumoniae, supporting the hypothesis that a single $b l a$. ${ }_{204}$-positive plasmid is spreading among various genetic backgrounds (Figure 2). One OXA-204-positive ST617 E. coli strain was identified in Tunisia in 2015 [14]. Of note, ST617 is a widespread ST type, associated with various beta-lactamase-encoding genes (CTX-M-15, NDM-1) $[34,35]$. Interestingly, ESBL-producing ST617 E. coli were recently recovered from companion and farm animals in Tanzania and from water samples in Tunisia [36,37].

In this study, between October 2012 and May 2014, OXA-204 ST9o E. coli strains were regularly identified. Concomitantly, OXA-204-producing ST147 K. pneumoniae isolates were identified in the same area (Paris and its suburbs) between August 2013 and May 2014. Although microbiological investigations were not conclusive, our results strongly suggest that the endoscope may have been contaminated with at least two OXA-204 producing isolates: ST90 E. coli that co-harboured a bla ${ }_{\text {CTX-M-15 }}$-carrying plasmid and ST147 $\mathrm{K}$. pneumoniae (Figure 2). Interestingly, following this outbreak the manufacturer released several notes concerning the reprocessing procedures of the endoscope [38] and updated in June 2015 the manual for reprocessing procedures which now includes reference to a novel brush (MAJ-1888/MyBrush) [39]. This dual outbreak was controlled in May 2014 after the sequestration of the endoscope suspected to be the source of the outbreak. Gastrointestinal endoscopy has previously been identified as a risk factor for infection and colonisation with carbapenemase-producing Enterobacteriaceae [40].

Four patients were colonised or infected with more than one OXA-204-producing enterobacterial species. Three patients were colonised with one OXA-204positive $E$. coli plus one OXA-204-producing K. pneumoniae, and one patient with one OXA-204-positive $E$. coli plus one OXA-204-producing $K$. pneumoniae and one additional OXA-204-positive S. marcescens. Those results suggest a high conjugative ability of the OXA204-IncA/C-type plasmids. As shown for OXA-48 [41],
OXA-204 is associated with an efficient genetic vehicle, thus promoting the interspecies spread of $b l a_{\text {oxA. }}$. ${ }_{204}$-carrying plasmids among various enterobacterial species in the same patient. In addition, as previously reported, endoscopy-associated transmission of carbapenemase-producing Enterobacteriaceae (CPE) might result in long-term carriage of the acquired CPE [42] that poses a risk of further secondary outbreaks from primary infected or colonised patients. Indeed, these patients are often at high risk of recurrence of a hepato-biliary infection that needs to be treated by endoscopic procedures. To decrease the risk of secondary outbreaks, we propose making a note in these these CPE patients' record and systematically screening them before performing any endoscopy.

The transposon Tn2016 was identified in 17 of the 29 isolates. The truncation of ISECP 1 by another IS may have stabilised this genetic structure on the IncA/C plasmid by disrupting the ISECP1 transposase activity. However, in the 12 remaining isolates, the ISEcp1 copy was intact and we can therefore speculate that the transposon made of ISEcp1and bla ${ }_{\mathrm{OXA}-204}$ is functional. ISECP1 is known to be an efficient genetic vehicle for spreading clinically significant beta-lactamases such as CMY or CTX-M-15 $[43,44]$. The association of bla ${ }_{\text {OXA-204 }}$ with an intact copy of ISECP1 on the one hand and an IncA/C broad host range plasmid on the other might increase the capability of the bla $a_{\text {OXA-204 }}$ to disseminate among various genetic elements (plasmids, chromosome, etc) and among various bacterial species.

\section{Acknowledgements}

We thank the platform Genotyping of Pathogens and Public Health (Institut Pasteur, Paris, France) for coding MLST alleles and profiles and making them available at www.pasteur.fr/mlst.

Funding: This work was supported by grants from French Ministry of Health and The French Public Health Agency (Santé publique France).

\section{Conflict of interest}

None declared.

\section{Authors' contributions}

$A P, L D, L P$ and $P N$ designed the study. AP, SB, GC and LD performed the experiments and recorded the data. AP, LD, PN, LP, TN, HB and VP contributed to the writing of the manuscript.

PN was head of the Associated French NRC for Antibiotic Resistance (division of carbapenemase-producing Enterobacteriaceae) from 2012 to July 2013.

\section{References}

1. Poirel L, Potron A, Nordmann P. OXA-48-like carbapenemases: the phantom menace. J Antimicrob Chemother. 2012;67(7):1597606. https://doi.org/10.1093/jac/dks121 PMID: 22499996 
2. Dortet L, Cuzon G, Nordmann P. Dissemination of carbapenemase-producing Enterobacteriaceae in France, 2012. J Antimicrob Chemother. 2014;69(3):623-7. https://doi. org/10.1093/jac/dkt433 PMID: 24275115

3. Albiger B, Glasner C, Struelens MJ, Grundmann H, Monnet DLEuropean Survey of Carbapenemase-Producing Enterobacteriaceae (EuSCAPE) working group. Carbapenemaseproducing Enterobacteriaceae in Europe: assessment by national experts from 38 countries, May 2015. Euro Surveill. 2015;20(45):30062. https://doi.org/10.2807/1560-7917. ES.2015.20.45.30062 PMID: 26675038

4. Vaux S, Carbonne A, Thiolet JM, Jarlier V, Coignard BRAISIN and Expert Laboratories Groups. Emergence of carbapenemaseproducing Enterobacteriaceae in France, 2004 to 2011. Euro Surveill. 2011;16(22):19880. https://doi.org/10.2807/ ese.16.22.19880-en PMID: 21663708

5. Oueslati S, Nordmann P, Poirel L. Heterogeneous hydrolytic features for OXA-48-like $\beta$-lactamases. J Antimicrob Chemother. 2015;70(4):1059-63. https://doi.org/10.1093/jac/ dku524 PMID: 25583748

6. Potron A, Nordmann P, Lafeuille E, Al Maskari Z, Al Rashdi F, Poirel L. Characterization of OXA-181, a carbapenemhydrolyzing class $D$-lactamase from Klebsiella pneumoniae. Antimicrob Agents Chemother. 2011;55(10):4896-9. https:// doi.org/10.1128/AAC.00481-11 PMID: 21768505

7. Potron A, Nordmann P, Poirel L. Characterization of OXA-204, a carbapenem-hydrolyzing class D $\beta$-lactamase from Klebsiella pneumoniae. Antimicrob Agents Chemother. 2013;57(1):633-6. https://doi.org/10.1128/AAC.01034-12 PMID: 23114766

8. Oteo J, Hernández JM, Espasa M, Fleites A, Sáez D, Bautista V, et al. Emergence of OXA-48-producing Klebsiella pneumoniae and the novel carbapenemases OXA-244 and OXA-245 in Spain. J Antimicrob Chemother. 2013;68(2):317-21. https://doi. org/10.1093/jac/dks383 PMID: 23034714

9. Potron A, Rondinaud E, Poirel L, Belmonte O, Boyer S, Camiade $S$, et al. Genetic and biochemical characterisation of OXA232, a carbapenem-hydrolysing class D $\beta$-lactamase from Enterobacteriaceae. Int J Antimicrob Agents. 2013;41(4):325 9. https://doi.org/10.1016/j.ijantimicag.2012.11.007 PMID: 23305656

10. Potron A, Poirel L, Dortet $L$, Nordmann P. Characterisation of OXA-244, a chromosomally-encoded OXA-48-like $\beta$-lactamase from Escherichia coli. Int J Antimicrob Agents. 2016;47(1):1023. https://doi.org/10.1016/j.ijantimicag.2015.10.015 PMID: 26655033

11. Poirel L, Castanheira M, Carrër A, Rodriguez CP, Jones RN, Smayevsky J, et al. OXA-163, an OXA-48-related class D $\beta$-lactamase with extended activity toward expandedspectrum cephalosporins. Antimicrob Agents Chemother. 2011;55(6):2546-51. https://doi.org/10.1128/AAC.00022-11 PMID: 21422200

12. Gomez S, Pasteran F, Faccone D, Bettiol M, Veliz O, De Belder D, et al. Intrapatient emergence of OXA-247: a novel carbapenemase found in a patient previously infected with OXA-163-producing Klebsiella pneumoniae. Clin Microbiol Infect. 2013;19(5):E233-5. https://doi.org/10.1111/14690691.12142 PMID: 23402333

13. Dortet L, Oueslati S, Jeannot K, Tandé D, Naas T, Nordmann P. Genetic and biochemical characterization of OXA-405, an OXA48-type extended-spectrum $\beta$-lactamase without significant carbapenemase activity. Antimicrob Agents Chemother. 2015;59(7):3823-8. https://doi.org/10.1128/AAC.05058-14 PMID: 25870062

14. Charfi K, Mansour W, Khalifa AB, Mastouri M, Aouni M, Mammeri H. Emergence of OXA-204 $\beta$-lactamase in Tunisia. Diagn Microbiol Infect Dis. 2015;82(4):314-7. https://doi. org/10.1016/j.diagmicrobio.2015.04.003 PMID: 26001616

15. Grami R, Mansour W, Ben Haj Khalifa A, Dahmen S, Chatre P, Haenni M, et al. Emergence of ST147 Klebsiella pneumoniae producing OXA-204 carbapenemase in a University Hospital, Tunisia. Microb Drug Resist. 2016;22(2):137-40. https://doi. org/10.1089/mdr.2014.0278 PMID: 26447939

16. European Committee on Antimicrobial Susceptibility Testing (EUCAST). Breakpoint tables for interpretation of MICs and zone diameters. Version 6.0. Växjö: EUCAST; 2016. Available from: http://www.eucast.org/fileadmin/src/media/PDFs/ EUCAST_files/Breakpoint_tables/v_6.o_Breakpoint_table.pdf

17. Poirel L, Dortet L, Bernabeu S, Nordmann P. Genetic features of blaNDM-1-positive Enterobacteriaceae. Antimicrob Agents Chemother. 2011;55(11):5403-7. https://doi.org/10.1128/ AAC.00585-11 PMID: 21859933

18. Poirel L, Walsh TR, Cuvillier V, Nordmann P. Multiplex PCR for detection of acquired carbapenemase genes. Diagn Microbiol Infect Dis. 2011;70(1):119-23. https://doi.org/10.1016/j. diagmicrobio.2010.12.002 PMID: 21398074
19. Diancourt L, Passet V, Verhoef J, Grimont PA, Brisse S. Multilocus sequence typing of Klebsiella pneumoniae nosocomial isolates. J Clin Microbiol. 2005;43(8):4178-82. https://doi.org/10.1128/JCM.43.8.4178-4182.2005 PMID: 16081970

20. Klebsiella sequence typing. Paris: Institut Pasteur. [Accessed: 15 Jan 2017). Available from: http://bigsdb.pasteur.fr/ klebsiella/klebsiella.html

21. EnteroBase. Escherichia coli MLST database. Warwick: EnteroBase. [ Accessed: 15 Jan 2017). Available from: http:// mlst.ucc.ie/mlst/dbs/Ecoli

22. Kieser T. Factors affecting the isolation of CCC DNA from Streptomyces lividans and Escherichia coli. Plasmid. 1984;12(1):19-36. https://doi.org/10.1016/0147619X(84)90063-5 PMID: 6387733

23. Potron A, Poirel L, Nordmann P. Derepressed transfer properties leading to the efficient spread of the plasmid encoding carbapenemase OXA-48. Antimicrob Agents Chemother. 2014;58(1):467-71. https://doi.org/10.1128/ AAC.01344-13 PMID: 24189247

24. Carattoli A, Bertini A, Villa L, Falbo V, Hopkins KL, Threlfall EJ. Identification of plasmids by PCR-based replicon typing. J Microbiol Methods. 2005;63(3):219-28. https://doi. org/10.1016/j.mimet.2005.03.018 PMID: 15935499

25. Circulaire $n^{\circ} 2003-591 \mathrm{du} 17 / 12 / 2003$ relative aux modalités de traitement manuel pour la désinfection des endoscopes non autoclavables dans les lieux de soins. [Circular no. 2003-591 of 17 Dec 2003 relating to the manual treatment modalities for the disinfection of non-autoclavable endoscopes in places of care]. Paris: Ministere de la Sante, de la Famille et des Personnes handicapees; 2003. French. Available from: http://circulaires. legifrance.gouv.fr/pdf/2009/04/cir_8584.pdf

26. Eléments d'assurance qualité en hygiène relatifs au contrôle microbiologique des endoscopes et à la traçabilité en endoscopie. [Elements of quality assurance in hygiene relating to microbiological control of endoscopes and traceability in endoscopy]. Paris: Ministère des Affaires sociales et de la Santé; 2007. Franch. Available from: http://social-sante.gouv. $\mathrm{fr} / \mathrm{IMG} / \mathrm{pdf} / \mathrm{microbio}$ endoscopes-2.pdf

27. Potron A, Poirel L, Rondinaud E, Nordmann P. Intercontinental spread of OXA-48 $\beta$-lactamase-producing Enterobacteriaceae over a 11-year period, 2001 to 2011. Euro Surveill. 2013;18(31):20549. https://doi.org/10.2807/1560-7917. ES2013.18.31.20549 PMID: 23929228

28. Mushtaq S, Irfan S, Sarma JB, Doumith M, Pike R, Pitout J, et al. Phylogenetic diversity of Escherichia coli strains producing NDM-type carbapenemases. J Antimicrob Chemother. 2011;66(9):2002-5. https://doi.org/10.1093/jac/dkr226 PMID: 21669947

29. Österblad M, Kirveskari J, Hakanen AJ, Tissari P, Vaara M, Jalava J. Carbapenemase-producing Enterobacteriaceae in Finland: the first years (2008-11). I Antimicrob Chemother. 2012;67(12):2860-4. https://doi.org/10.1093/jac/dks299 PMID: 22855858

30. Gamal D, Fernández-Martínez M, Salem D, El-Defrawy I, Montes LA, Ocampo-Sosa AA, et al. Carbapenem-resistant Klebsiella pneumoniae isolates from Egypt containing blaNDM-1 on IncR plasmids and its association with rmtF. Int J Infect Dis. 2016;43:17-20. https://doi.org/10.1016/j.ijid.2015.12.003 PMID: 26686939

31. Shin J, Baek JY, Cho SY, Huh HJ, Lee NY, Song JH, et al. blaNDM5-bearing IncFll-type plasmids of Klebsiella pneumoniae sequence type 147 transmitted by cross-border transfer of a patient. Antimicrob Agents Chemother. 2016;60(3):1932-4. https://doi.org/10.1128/AAC.02722-15 PMID: 26824953

32. Rodrigues C, Machado E, Ramos H, Peixe L, Novais Â. Expansion of ESBL-producing Klebsiella pneumoniae in hospitalized patients: a successful story of international clones (ST15, ST147, ST336) and epidemic plasmids (IncR, IncFIIK). Int J Med Microbiol. 2014;304(8):1100-8. https://doi. org/10.1016/j.ijmm.2014.08.003 PMID: 25190354

33. Bathoorn E, Tsioutis C, da Silva Voorham JM, Scoulica EV, Ioannidou E, Zhou K, et al. Emergence of pan-resistance in KPC-2 carbapenemase-producing Klebsiella pneumoniae in Crete, Greece: a close call. J Antimicrob Chemother. 2016;71(5):1207-12. https://doi.org/10.1093/jac/dkv467 PMID: 26817488

34. Aibinu I, Odugbemi T, Koenig W, Ghebremedhin B. Sequence type ST131 and ST10 complex (ST617) predominant among CTX-M-15-producing Escherichia coli isolates from Nigeria. Clin Microbiol Infect. 2012;18(3):E49-51. https://doi.org/10.1111/ j.1469-0691.2011.03730.x PMID: 22192452

35. Torres-González P, Bobadilla-Del Valle M, Tovar-Calderón E, Leal-Vega F, Hernández-Cruz A, Martínez-Gamboa A, et al. Outbreak caused by Enterobacteriaceae harboring NDM-1 metallo- $\beta$-lactamase carried in an IncFII plasmid in a tertiary care hospital in Mexico City. Antimicrob Agents Chemother. 
2015;59(11):7080-3. https://doi.org/10.1128/AAC.00055-15 PMID: 26282410

36. Seni J, Falgenhauer L, Simeo N, Mirambo MM, Imirzalioglu C, Matee M, et al. Multiple ESBL-producing Escherichia coli sequence types carrying quinolone and aminoglycoside resistance genes circulating in companion and domestic farm animals in Mwanza, Tanzania, harbor commonly occurring plasmids. Front Microbiol. 2016;11;7:142.

37. Ben Said L, Jouini A, Alonso CA, Klibi N, Dziri R, Boudabous $A$, et al. Characteristics of extended-spectrum $\beta$-lactamase (ESBL)- and pAmpC beta-lactamase-producing Enterobacteriaceae of water samples in Tunisia. Sci Total Environ. 2016;550:1103-9. https://doi.org/10.1016/j. scitotenv.2016.01.042 PMID: 26871556

38. Information de sécurité. Ecouvillonnage de l'érecteur du Duodénoscope TJF Q180V. [Safety information. Swabbing the TJF Q180V duodenoscope erector]. Rungis Cedex: OLYMPUS France S.A.S; 2014. French. Available from: http://ansm. sante.fr/content/download/65965/844017/version/2/file/mes140807-Duodenoscope-Olympus.pdf

39. Mise à jour du mode d'emploi et nouvelles de nettoyage pour le duodénoscope OLYMPUS TJF - Q180V. Guide de nettoyage et écouvillons de nettoyage MAJ-1888/MyBrush. [Update of the user manual and cleaning news for the OLYMPUS TJF Q180V duodenoscope - MAJ-1888. MyBrush cleaning guide and cleaning swabs]. Rungis Cedex: OLYMPUS France S.A.S; 2015. French. Available from: http://ansm.sante.fr/content/ download/78191/991251/version/1/file/mes_150619_olympus. pdf

40. Muscarella LF. Risk of transmission of carbapenem-resistant Enterobacteriaceae and related "superbugs" during gastrointestinal endoscopy. World J Gastrointest Endosc. 2014;6(10):457-74. https://doi.org/10.4253/wjge.v6.i10.457 PMID: 25324917

41. Arana DM, Saez D, García-Hierro P, Bautista V, FernándezRomero S, Ángel de la Cal M, et al. Concurrent interspecies and clonal dissemination of OXA-48 carbapenemase. Clin Microbiol Infect. 2015;21(2):148.e1-4. https://doi.org/10.1016/j. cmi.2014.07.008 PMID: 25596781

42. Dortet L, Naas T, Boytchev I, Fortineau N. Endoscopyassociated transmission of carbapenemase-producing Enterobacteriaceae: return of 5 years' experience. Endoscopy. 2015;47(6):561. https://doi.org/10.1055/s-0034-1392098 PMID: 26030891

43. Nakano R, Okamoto R, Nagano N, Inoue M. Resistance to gramnegative organisms due to high-level expression of plasmidencoded ampC $\beta$-lactamase blaCMY-4 promoted by insertion sequence ISEcp1. J Infect Chemother. 2007;13(1):18-23. https://doi.org/10.1007/s10156-006-0483-6 PMID: 17334724

44. Poirel L, Decousser JW, Nordmann P. Insertion sequence ISEcP1B is involved in expression and mobilization of a bla(CTX-M) $\beta$-lactamase gene. Antimicrob Agents Chemother. 2003;47(9):2938-45. https://doi.org/10.1128/AAC.47.9.29382945.2003 PMID: 12936998

\section{License and copyright}

This is an open-access article distributed under the terms of the Creative Commons Attribution (CC BY 4.0) Licence. You may share and adapt the material, but must give appropriate credit to the source, provide a link to the licence, and indicate if changes were made.

This article is copyright of the authors, 2017. 